\title{
Confirmation of the Presence of the Red-Capped Mangabey (Cercocebus torquatus) in Mayumba National Park, Southern Gabon, and Conkouati-Douli National Park, Southern Republic of Congo
}

Author(s): Fiona Maisels, Quevain Pambou Makaya and Jean-Robert Onononga

Source: Primate Conservation, 22(1):111-115. 2007.

Published By: Conservation International

DOI: http://dx.doi.org/10.1896/052.022.0110

URL: http://www.bioone.org/doi/full/10.1896/052.022.0110

BioOne (www.bioone.org) is a nonprofit, online aggregation of core research in the biological, ecological, and environmental sciences. BioOne provides a sustainable online platform for over 170 journals and books published by nonprofit societies, associations, museums, institutions, and presses.

Your use of this PDF, the BioOne Web site, and all posted and associated content indicates your acceptance of BioOne's Terms of Use, available at www.bioone.org/page/terms of use.

Usage of BioOne content is strictly limited to personal, educational, and non-commercial use. Commercial inquiries or rights and permissions requests should be directed to the individual publisher as copyright holder. 


\title{
Confirmation of the Presence of the Red-capped Mangabey (Cercocebus torquatus) in Mayumba National Park, Southern Gabon, and Conkouati-Douli National Park, Southern Republic of Congo
}

\author{
Fiona Maisels ${ }^{1}$, Quevain Pambou Makaya² and Jean-Robert Onononga ${ }^{3}$ \\ ${ }^{1}$ Wildlife Conservation Society, Bronx, New York, USA \\ ${ }^{2}$ Wildlife Conservation Society, Gabon, Libreville \\ ${ }^{3}$ Wildlife Conservation Society, Brazzaville, Congo
}

\begin{abstract}
Surveys were carried out in Gabon in Mayumba National Park in 2006 and in the Conkouati-Douli National Park in the Republic of Congo in 1996 and 2000. Red-capped mangabeys, Cercocebus torquatus, (also known as white-collared mangabeys) were recorded in both parks in areas about $30 \mathrm{~km}$ distant from hunting pressure. The distribution of this species is known to extend from west of the Niger River to just south of the Ogooue River in Gabon, but its presence in Southern Congo, while suspected in 1949, had never been confirmed. These observations extend the confirmed published range by about $250 \mathrm{~km}$ south, and into the Republic of Congo. The published distribution is probably much too uniform, as the species now appears to be absent in areas with even low to medium hunting pressure. We call for resurveys of the sites where it has been previously recorded in the past to confirm continued presence and to clarify its conservation status. We also call for surveys along the coastal forests outside protected areas, especially within Gabon, to identify remaining populations.

Résumé: Les recensements de la faune ont été menés au Gabon dans le Parc National de Mayumba en 2006 et dans le Parc National de Conkouati-Douli en République du Congo en 1996, puis en 2000. La presence du Cercocebus torquatus a été confirmée dans les deux parcs a environ $30 \mathrm{~km}$ des zones de préssion de chasse. Cependant, la distribution connue de cette espèce part de l'ouest du Nigeria jusqu'au sud du fleuve Ogooué au Gabon; sa presence avait été supposée au sud du Congo en 1949 mais n'avait jamais été confirmée. Les observations que nous avons faites augmentent la distribution confirmée de cette espèce autour de 250 $\mathrm{km}$ vers le sud, et confirme sa présence en République du Congo. Néanmoins, la distribution dans la littérature est probablement trop uniforme, parce qu'il semble que l'espèce est absente dans les sites où la pression de chasse est faible ou moyenne. Nous suggérons que les sites ou l'espèce était connue auparavant soient réexaminés pour confirmer sa présence et clarifier son statut de conservation. Nous suggérons aussi que les forets le long de la côte Atlantique hors des aires protégées, surtout au Gabon, soient examinées afin d'identifier les populations restantes.
\end{abstract}

Key Words: Red-capped mangabey, white-collared mangabey, Cercocebus, biogeography, distribution, Congo

\section{Introduction}

The red-capped mangabey Cercocebus torquatus (Kerr, 1792 ) is a medium-sized (females $5-8 \mathrm{~kg}$; males $7-12.5 \mathrm{~kg}$ ) (Kingdon 1997) monkey that occurs along the Atlantic forest coastal area of west and central Africa (Malbrant and Maclatchy 1949; Lee et al. 1988; Oates 1996; Kingdon 1997; IEA 1998; Gautier-Hion et al. 1999). Opinions differ as to its taxonomic status: IEA considers the species to include both $C$. atys (sooty mangabey) as $C$. torquatus atys, as well as the red-capped mangabey (as C. t. torquatus), whereas Kingdon (1997) and Oates (1996) keep C. atys and C. torquatus separate. Here we refer to $C$. torquatus as the animals living east of the Dahomey gap, in other words from the Nigeria-Benin border eastwards and southwards along the coast.

According to Malbrant and Maclatchy it was (in 1949) "abundant in the coastal region of Gabon and Moyen-Congo" (now the Republic of Congo). They write "The Congo (river) seems to be its southernmost limit: at least Schouteden has not recorded it in the Belgian Congo" suggesting that the Congo River marked the southern limit of its distribution. A survey forty years later by Dowsett and Granjon (1991) in the Kouilou area, just south of the present Conkouati-Douli National Park (Fig. 1), showed no sign of this species. Because all place names cited in Malbrant and Maclatchy's text were actually in Gabon and not Moyen-Congo, Dowsett and Granjon wrote 
that "we accept, with hesitation, its past presence in Congo, but there are no recent confirmations". It is highly possible that the species had been hunted out of the area surveyed by Dowsett and Granjon, as had most of the other large monkey species (Dowsett and Granjon 1991; Wilson and Wilson 1991).

In 1996, the Status Survey and Conservation Plan for African Primates (Oates 1996) called for more surveys in southwest Gabon. This note reports on the presence of redcapped mangabeys recorded during surveys on both sides of the Gabon-Congo border on the Atlantic shore, and discusses the implications for their conservation.

\section{Observations}

Troops of red-capped mangabeys were seen during surveys in 1996 and in 2000 in what is now the Conkouati-Douli National Park (Republic of Congo: Fig. 1). Mangabeys were recorded on sixteen occasions at a number of sites in the area. They were sometimes in polyspecific groups with one or more of the guenons Cercopithecus nictitans, $C$. pogonias and $C$. cephus. Groups were also seen three times in a third survey in 2006 in the Mayumba National Park in Gabon, just on the other side of the border (Fig. 1). Red-capped mangabeys are fairly conspicuous because they are very vocal and relatively large. They also tend to be spread through the undergrowth and in the trees (they are semi-terrestrial), moving branches and leaves as they forage. Red-capped mangabeys are sympatric with mandrills at both the Conkouati and the Mayumba sites, and both species were seen in large groups at both sites.

During the two Conkouati surveys, red-capped mangabeys were never seen in the forests near the coast. This was assumed to be due to habitat preference - there is a marked gradient in vegetation type with increasing distance from the

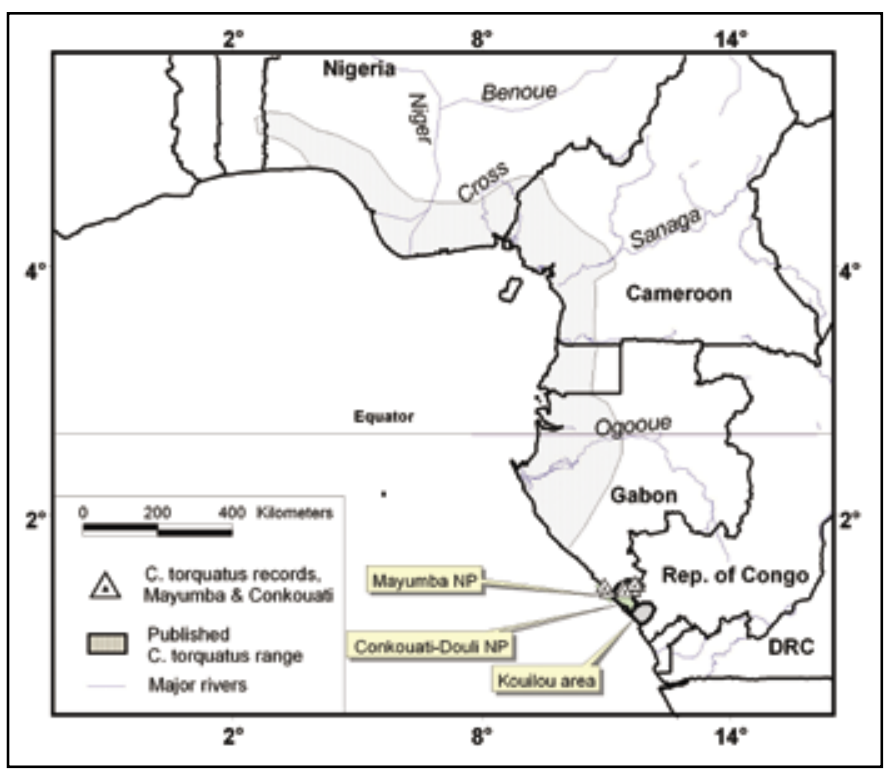

Figure 1. Range of Cercocebus torquatus, after the "certain" range of IEA (1998), and the recent records from Conkouati-Douli and Mayumba National Parks, Gabon and Congo. coast. The mangabeys seen in Conkouati were all in steeply sloping, closed-canopy forest and in gallery forests in the savannas, more than $30 \mathrm{~km}$ from the coast. The coastal forests tend to be very marshy. However in the Mayumba National Park, they were common right up to a few hundred metres behind the beach, in the littoral forests along the shore, and, indeed, in the marsh forests along the lagoon. In Mayumba, however, they were not recorded closer than $30 \mathrm{~km}$ from the Congo-Gabon border, although they were seen at several sites north of this limit, still within the park.

Data on wildlife and signs of human presence were collected during all three surveys. In Conkouati, in 1996 and 2000, hunting was intensive all along the coast. Several large villages are situated inside the protected area along the coast. Densities of large mammals were very low along the littoral forests there (extending to about $30 \mathrm{~km}$ from the coast). The only exception was chimpanzees, which are protected by local custom in this region. In Mayumba, the area along the CongoGabon border (on the Gabon side) had recently been exploited by a logging company, so access into the area was relatively easy along the road network.

Discussions with Congolese and Gabonese field staff revealed that Congolese hunters were in the habit of crossing the border to hunt in the Mayumba region of Gabon. This was partly because of the paucity of wildlife remaining on the Congo side of the border, and partly because the risk of being apprehended by the wildlife (or immigration) authorities on the Gabon side was perceived to be very low. The meat would then be walked back to the Congo border and transported by vehicle to Pointe-Noire, the regional capital of southern Congo, for the bushmeat trade.

\section{Discussion}

Cercocebus torquatus was apparently absent, or at densities too low to detect, in Mayumba, Gabon, within $30 \mathrm{~km}$ from the Congolese border, and it was not seen on our surveys within $30 \mathrm{~km}$ of the coastal villages in Conkouati. Human pressure is largely responsible for their present distribution at these sites. The areas where the monkey was not seen were identified by signs of human activities in the two parks, as well by conversations with local hunters (converted to field assistants) to be areas subject to the highest hunting pressure at the time the data were collected. This would also explain why, even fifteen years ago, the survey team in Kouilou (Dowsett and Granjon 1991) failed to find this species (and also did not record any other medium-sized monkey except a few Cercopithecus nictitans and C. cephus: they also said that grey cheeked mangabeys [Lophocebus albigena] and mandrills [Mandrillus sphinx] had become very rare in the area near the villages). The large size of the red-capped mangabey, semi-terrestrial habits, and conspicuous and quite far-carrying vocalizations (Gautier-Hion et al. 1999) make it easy to locate and a worthy reward for the cost of a single cartridge. It is also possible that, being semi-terrestrial, it is often caught in wire snares commonly set around villages to trap small ungulates 
and larger rodents. Even in 1991 in the Kouilou area south of Conkouati in Congo, hunters recognized that all large mammals had become rare (Dowsett-Lemaire and Dowsett 1991; Wilson and Wilson 1991), and they particularly noted that monkeys had become very hard to find since the introduction of firearms in the 1960s. This is echoed in the complaints of local hunters within the Conkouati villages in 1996 and 2000, situated even further from the commercial bushmeat market of Point Noire.

At present, the species is considered Low Risk (Near threatened) in the IUCN Red Data List (IUCN 2006), and is on Appendix II of CITES (Inskipp and Gillett 2005). Our data show that red-capped mangabeys occur about $250 \mathrm{~km}$ further south than was previously reported in the published accounts of its southern range (Kingdon 1997; IEA 1998), and we have been able to confirm that they occur in the Republic of Congo as was suggested by Malbrant and Maclatchy (1949). It is likely that this species can only maintain populations where hunting pressure is relatively low. Its quite large distribution contains only a few protected areas, but in not all of them is there effective anti-poaching, and in many of them the species may already have been drastically reduced in number. The alarm bells have already sounded in previous IUCN publications (Lee et al. 1988; Oates 1996). Current threats are listed as habitat loss and harvesting (IUCN 2006).

In Gabon, red-capped mangabeys occur in the National Parks of Loango, Moukalaba-Doudou, and Pongara (Le Duc Yeno 2006; Latour 2006, Maisels (unpubl. data), but they have not been recorded in the Monts de Cristal, despite an extensive survey effort in 2005 (Aba'a Nseme 2006; Maisels et al. 2006).

Surveys in Equatorial Guinea in 1998 failed to find them in the three proposed (at the time) protected areas of Rio Campo, Monts de Mitra, and Altos de Nsork (Larison et al. 1999). They had, however, been present in the first two areas in 1967 (Sabater Pi and Jones 1967) and Fa (1991, in Larison et al. 1999) was told by local hunters that they still occurred in the Altos de Nsork in 1991. They were still present in Monte Alen in 1994 (Garcia and Mba 1997). However, unless those surveying are familiar with the call of the species, they may miss them if they are not actually seen.

Red-capped mangabeys were known to occur in southern Cameroon by Malbrant and Maclatchy (1949), where, however, they noted that the species was rare (Jeannin 1936, in Malbrant and Maclatchy 1949). They have been recorded more recently in several areas in south-west Cameroon (for example, in Banyang Mbo: Willcox and Nambu 2006; Greengrass and Maisels 2007; and in Korup: Waltert et al. 2002), but at very low densities. They have been seen on Mt. Etinde next to Mt. Cameroon (Nku 2004). They were not, however, recorded during the fairly extensive surveys of the Takamanda forest 1997-2002, nor were they known to local people (Sunderland-Groves and Maisels 2003) even though they were there twenty years ago (Thomas 1988) and were collected from Atolo in 1933 (just to the northeast of the Takamanda forest) (Sanderson 1940). Nku (2001) still had them on the list of large mammals of Campo Ma'an, but it is not clear if his data was from direct observations or from a literature review, in which case the sightings could have been much earlier; they were certainly present there in the 1980s (Mitani 1989).

Schlitter et al. (1973) published the range if this species in Nigeria, which was basically all along the coast from east to west nearly up to the western border. More recently, redcapped mangabeys have been shown to still be present in the following areas: southwest Nigeria (Greengrass 2006); the Oban area and between the Niger and the Cross rivers (Oates 1996; Oates et al. 2004; see also Happold 1987). Oates (pers. comm.) suggested that they may be naturally less common in Cameroon and Nigeria because of competition with drills Mandrillus leucophaeus. However, in Mayumba and Conkouati large troops of both mandrills Mandrillus sphinx (which are in a similar niche to drills) and of red-capped mangabeys were recorded living sympatrically.

We suggest that, in future surveys, attention be paid to the presence (or absence) of Cercocebus torquatus. Their vocalizations are fairly far-carrying and, although slightly similar to those of Lophocebus albigena, are slower and more raucous. Survey teams should ensure that they are familiar with the calls of both species before fieldwork begins (using, for example, the reference CD of Gautier-Hion et al. 1999). Museum records should be checked, to further clarify the historical range of the species, and then, where possible, sites outside Gabon where they used to occur should be checked to verify if they still do, with particular attention on Equatorial Guinea and southern Cameroon, including the DoualaEdea Reserve, Mount Cameroon/Etinde, and Campo Ma'an. We also call for surveys along the coastal forests outside protected areas, where possible, especially in Gabon, to identify remaining populations. These data will clarify the distribution and conservation of this species and should play a part in any future assessment of its Red List status.

\section{Acknowledgments}

We thank the Governments of Gabon and Congo for their support for conservation in their countries, including the Conseil National des Parcs Nationaux (Gabon) and the Ministry of Forests in both countries. Conservateurs Solange Ngouessono and Noé Mabiala helped enormously at the two sites. Thanks to Richard Parnell, Aimee Sanders and the staff of the WCS Mayumba Project, to Bruno Paris and Marcel Taty and their staff (IUCN-Conkouati), Bryan Curran, then of the WCS-Congo Protected Areas project, and to Aliette Jamart and her staff (HELP-Congo). The work of field assistants Souami Nzassi and Alain Djimbi Mavoungou (in Gabon) and of 'Farel' Mavoungou François and Tchitiamouna Guy-Noël (in Congo) was greatly appreciated. The Wildlife Conservation Society, USAID, and IUCN provided support for the authors. A particular thank-you goes to John Oates for his pertinent comments and suggestions and his knowledge of the species' range, which have greatly improved the manuscript. 


\section{Literature Cited}

Aba'a Nseme, R. 2006. Abondance relative des grands mammifères et des activités humaines au parc National des Monts de Cristal et sa peripherie. Report, Wildlife Conservation Society (WCS), Gabon, Libreville.

Dowsett-Lemaire, F. and R. Dowsett. 1991. Observations complementaires sur quelques grands mammiferes dans le bassin du Kouilou au Congo. Tauraco Research Report 4: $291-96$.

Dowsett, R. J. and L. Granjon. 1991. Liste préliminaire des mammifères du Congo. Flore et faune du bassin de Kouilou (Congo) et leur exploitation. Tauraco Research Report (4): 297-310.

Fa, J. E. 1991. Conservación de los Ecosistemas Forestales de Guinea Ecuatorial. UICN - Unión Mundial para la Naturaleza, Comisión de las Comunidades Europeas, Gland, Switzerland.

Garcia, J. E. and J. Mba. 1997. Distribution, status and conservation of primates in Monte Alen National Park, Equatorial Guinea. Oryx 31: 67-76.

Gautier-Hion, A., M. Colyn and J. -P. Gautier. 1999. Histoire Naturelle des Primates d'Afrique Centrale. ECOFAC, Libreville, Gabon.

Greengrass, E. J. 2006. A survey of chimpanzees in southwest Nigeria. Report, NCF-WCS Biodiversity Research Programme, Wildlife Conservation Society (WCS), New York. 51pp.

Greengrass, E. J. and F. Maisels. 2007. Conservation of the Nigerian-Cameroon Chimpanzee $P$. t. vellerosus (and other mammals) in and around the Banyang-Mbo Wildlife Sanctuary, South-west Province, Cameroon. Report, WCS Cameroon Programme, Wildlife Conservation Society (WCS), New York. 74pp.

Groves, C. P. 2001. Primate Taxonomy. Smithsonian Institution Press, Washington, DC.

Groves, C. P. 2005. Order Primates. In: Mammal Species of the World: A Taxonomic and Geographic Reference, 3rd Edition, Vol. 1, D. E. Wilson and D. M. Reeder (eds.), pp.111 - 184. Johns Hopkins University Press, Baltimore.

Grubb, P., T. M. Butynski, J. F. Oates, S. K. Bearder, T. R. Disotell, C. P. Groves and T. T. Struhsaker. 2003. Assessment of the diversity of African primates. Int. J. Primatol. 24(6): $1301-1357$.

Happold, D. C. D. 1987. The Mammals of Nigeria. Clarendon Press, Oxford, UK.

IEA. 1998. Cercocebus torquatus (Kerr, 1792). African Mammals Databank - A Databank for the Conservation and Management of the African Mammals, 2 vols. Institute of Applied Ecology (IEA), European Commission Directorate, Bruxelles. Website: <http:/gorilla.bio.uniroma1.it/ amd/amd062.html $>$. Accessed 20 July 2006.

Inskipp, T. G. and H. J. Gillett. 2005. Checklist of CITES species and Annotated CITES Appendices and reservations. CITES Secretariat and UNEP-WCMC, Geneva, Switzerland and Cambridge, UK.
IUCN. 2006. 2006 IUCN Red List of Threatened Species. Website: <www.iucn.redlist.org>. Accessed: 8 January 2007.

Jeannin, A. 1936. Les Mammifères sauvages du Cameroun Lechevalier, Paris.

Kingdon, J. 1997. The Kingdon Field Guide to African Mammals. Academic Press, London.

Larison, B., T. B. Smith, D. Girman, D. Stauffer, B. Milá, R. C. Drewes, C. E. Griswold, J. V. Vindum, D. Ubick, K. O'Keefe, J. Nguema, and L. Henwood. 1999. Biotic Surveys of Bioko and Rio Muni, Equatorial Guinea. Biodiversity Support Program, World Wildlife Fund, Washington, DC.

Latour, S. 2006. Recensement des elephants et de grands singes dans le region du parc national de Pongara (Gabon). Report, Wildlife Conservation Society (WCS) / Espèces Phares, Libreville, Gabon.

Le Duc Yeno, S. 2006. Suivi des grands mammifères dans le secteur Sud Parc National de Loango. Report, World Wide Fund for Nature (WWF), Libreville, Gabon.

Lee, P. C., J. Thornback and E. L. Bennett. 1988. Threatened Primates of Africa: The IUCN Red Data Book. IUCN, Gland, Switzerland, and Cambridge, UK.

Maisels, F., R. Aa'ba, G. Abitsi, M. Bechem, N. Bout, H. Kuehl, S. Latour, P. Walsh and M. Ella Akou. 2006. Gabon's national park system: Baseline wildlife and human impact surveys. In: Abstracts: Society for Conservation Biology, $20^{\text {th }}$ Annual Meeting, San José, California, USA, 24-28 June 2006. http://www.conbio.org/ Activities/Meetings/2006/oral_abstracts.pdf.

Malbrant, R. and A. Maclatchy. 1949. Faune de l'Equateur Africain Francais. Vol. 2: Mammifères. Lechevalier, Paris.

Mitani, M. 1989. Cercocebus torquatus: adaptive feeding and ranging behaviours related to seasonal fluctuations of food resources in the tropical rainforest of south-western Cameroon. Primates 30: 307-323.

Nku, E. 2001. Frequency of Large Mammal Visits to a Forest Clearing: A Case Study of Ecotourism Potential in the Campo Ma'an National Park, Southern Cameroon. MSc thesis, University of Kent, Canterbury, UK.

Nku, E. 2004. Large M ammal Reconnaissance Surveys of Mt. Etinde Forest Reserve, SW Province, Cameroon. Report, Wildlife Conservation Society (WCS) Cameroon, Limbe.

Oates, J. F. 1996. African Primates: Status Survey and Conservation Action Plan. The World Conservation Union - IUCN, Species Survival Commission (SSC), Primate Specialist Group (PSG), Gland.

Oates, J. F., R. A. Bergl and J. M. Linder. 2004. Africa's Gulf of Guinea forests: Biodiversity patterns and conservation priorities. Advances in Applied Biodiversity Science (6): 90pp. Center for Applied Biodiversity Science, Conservation International, Washington, DC.

Sanderson, I. T. 1940. The mammals of the north Cameroon forest area. Trans. Zool. Soc. Lond., 24: 623-725. 
Schlitter, D.A., J. Phillips and G. E. Kemp. 1973. The distribution of the white-collared mangabey, Cercocebus torquatus, in Nigeria. Folia Primatol. 19: 380-383.

Sunderland-Groves, J. L. and F. Maisels. 2003. Large mammals of Takamanda Forest Reserve, Cameroon. In: Takamanda - The Biodiversity of An African Rainforest, J. A. Comiskey, T. C. H. Sunderland and J. L. SunderlandGroves (eds.), Vol. 8, pp.111-127. Smithsonian Institution Press, Washington, DC.

Thomas, D. 1988. Status and Conservation of Takamanda Gorillas (Cameroon). Final Report, No. WWF-1613, World Wildlife Fund (WWF). Washington, DC.

Waltert, M., Lien, K. Faber and M. Muhlenberg. 2002. Further declines of threatened primates in the Korup Project Area, south-west Cameroon. Oryx 36: 257-265.

Willcox, A. S. and D. M. Nambu. 2007. Wildlife hunting practices and bushmeat dynamics of the Banyangi and Mbo people of southwestern Cameroon. Biol. Conserv. 134: $251-261$.

Wilson, V. J. and B. L. P. Wilson. 1991. La chasse traditionnelle et commerciale dans le sud-ouest du Congo. Tauraco Research Report (4): 279-289.

Authors'addresses

Fiona Maisels, Wildlife Conservation Society, 2300 Southern Boulevard, Bronx, New York, NY 10460-1099, USA, e-mail: $<$ fmaisels@wcs.org $>$.

Quevain Pambou Makaya, Wildlife Conservation Society, BP 7847, Libreville, Gabon, e-mail: <mckevin30@yahoo. com>.

Jean-Robert Onononga, Wildlife Conservation Society, BP 14537, Brazzaville, Congo, e-mail: <yhareve@yahoo.com>.

Received for publication: March 2007

Revised: August 2007 
